\title{
Clinical Study of Maternal and Perinatal Outcome in Pregnancies Complicated By Hellp Syndrome
}

\author{
Dr Rekha Gurumurthy ${ }^{1}$, Professor, Dr K B Gayathri ${ }^{2}$, Assistant professor \\ Dr Sravanthi ${ }^{3}$, Postgraduate, Dr Suma Varsha ${ }^{4}$, Post graduate \\ 1,2,4 (Dept of OBG, Mamatha Medical College, Khammam)
}

\begin{abstract}
:
Background \& Objectives: HELLP syndrome is considered a placenta-instigated, liver-targeted acute inflammatory condition, with elements of disordered immunological processes. HELLP syndrome can be a great masquerader with vague and varied nature of presenting complaints making its diagnosis difficult. Delay in diagnosis may be life threatening with poor maternal and perinatal outcome.

METHODS: 81 cases diagnosed of pregnancy induced hypertension(PIH) between May 2011 and April 2012 in department of obstetrics and gynaecology, Mamatha Medical College was included in the study. Of these 81, 18 cases fulfilled the criteria of HELLP. Maternal and perinatal outcome and also clinical and therapeutic factors affecting outcome were studied.
\end{abstract}

Results: The incidence of pregnancy induced hypertension $(P I H)$ during this period is $14.3 \%$, of these $22.2 \%$ fulfilled the criteria of HELLP. Maximum incidence is among age group 20 - 30 years (88\%). The incidence of maternal complications in our study was higher compared to Hemanth et al ${ }^{3}$, with incidence of pleural effusion/ ascites being highest (44.4\%). The incidence of intra uterine deaths was $33.3 \%$ and the incidence of neonatal deaths was $16.6 \%$.

Interpretation \& Conclusion: The reason for higher morbidity in our study is delay in identifying the problem by referring doctors. This study uncovers only the tip of the iceberg and HELLP syndrome in non PIH cases were not evaluated. Earlier diagnosis and intervention improves maternal and perinatal outcome

Keywords: HELLP, Pregnancy induced hypertension (PIH)

\section{Introduction}

The acronym HELLP was coined by Louis Weinstein in 1982 to describe a syndrome consisting of hemolysis $(\mathrm{H})$, elevated liver enzymes (EL) and low platelets (LP). HELLP syndrome develops in 1 of 1000 pregnancies overall ${ }^{1,2}$, and in $4-12 \%$ of the patients already affected by severe preeclampsia or eclampsia ${ }^{3}$. As many as $15-20 \%$ of the patients with HELLP syndrome do not have antecedent hypertension or proteinuria ${ }^{3}$. Onset is antepartum in $70 \%$ of the cases, usually in the third trimester, and within 48 hours of delivery in the other $30 \%$.

\section{Materials And Methods}

The present study was an observational study which has been carried out in the Department of Obstetrics and Gynaecology, Mamatha Medical College, Khammam.

81 cases attending the labor room were diagnosed of pregnancy induced hypertension between May 2011 and April 2012 . Of these 81, 18 cases fulfilled the criteria of HELLP. Maternal and perinatal outcome and also clinical and therapeutic factors effecting outcome were studied.

\section{Discussion}

HELLP is diagnosed by strict laboratory criteria of Hemolysis in Peripheral smear, Elevated liver enzymes AST $/ \mathrm{ALT}>/=70 \mathrm{IU} / \mathrm{L}, \mathrm{LDH}>/=600 \mathrm{IU} / \mathrm{L} \&$ Platelet count $<1,50,000 / \mathrm{microL}$

MISSISIPI CLASSIFICATION

CLASS I

- $\quad$ Platelets $<50000$

- $\quad$ AST or ALT $>70 I U / L$

- $\mathrm{LDH}>600 \mathrm{IU} / \mathrm{L}$

CLASS II

- $\quad$ Platelets 50000-100000

- $\quad$ AST or ALT >70IU/L 
- $\mathrm{LDH}>600 \mathrm{IU} / \mathrm{L}$

CLASS III

- $\quad$ Platelets 100000-150000

- $\quad$ AST or ALT $>40$ IU/L

- $\quad \mathrm{LDH}>600 \mathrm{IU} / \mathrm{L}$

Almost $90 \%$ of the patients will have a history of malaise for a few days prior to presentation ${ }^{4}$. Other common symptoms include epigastric or right upper quadrant abdominal pain, nausea, vomiting, headache and visual symptoms. The differential diagnosis include choleloithiasis, cholecystitis, hepatitis, acute fatty liver of pregnancy, pancreatitis, perforated peptic ulcer, severe hiatus hernia, pyelonephritis and Budd-Chiari syndrome $^{4}$. Thrombotic thrombocytopenic purpura (TTP) and hemolytic uremic syndrome (HUS) may also cloud the diagnosis of HELLP syndrome.

In the present study between the period May 2011 and April 2012, 81 cases(14.3\%) were diagnosed as pregnancy induced hypertension, of which 18 cases $(22.2 \%)$ fulfilled the criteria of HELLP

The 18 cases were categorized based on MISSISIPI classification

\begin{tabular}{|l|l|l|}
\hline CLASS & NO. OF PATIENTS & \% OF PATIENTS \\
\hline Class 1 & 4 & $22 \%$ \\
\hline Class 2 & 5 & $28 \%$ \\
\hline Class 3 & 9 & $50 \%$ \\
\hline
\end{tabular}

These 18 cases were classified according to MISSISIPI classification, with maximum incidence of $50 \%$ in Class 3 according to our study.

In this study the patients age group was between 18 and 30 years

\begin{tabular}{|l|l|l|}
\hline AGE ( in years) & NO.OF PATIENTS & \% OF PATIENTS \\
\hline $18-20$ yrs & 2 & $12 \%$ \\
\hline $20-30$ yrs & 16 & $88 \%$ \\
\hline
\end{tabular}

The age group in our study is between 18 and 30 years, with maximum incidence between $20-30$ years $(88 \%)$.

Distribution of patients according to the parity

\begin{tabular}{|l|l|l|}
\hline PARITY & NO.OF PATIENTS & \% OF PATIENTS \\
\hline Primi & 8 & $44 \%$ \\
\hline Multi & 18 & $56 \%$ \\
\hline
\end{tabular}

In our study, higher incidence was among multigravidae (56\%).

Distribution according to the period of gestation

\begin{tabular}{|l|l|l|}
\hline Gestation & NO.OF PATIENTS & $\%$ OF PATIENTS \\
\hline Preterm & 15 & $83.3 \%$ \\
\hline Term & 3 & $16.6 \%$ \\
\hline
\end{tabular}

In the present study of the 18 cases 15 cases $(83.3 \%)$ cases were preterm.

The incidence of maternal complications in this study is as follows

\begin{tabular}{|c|l|l|l|l|l|}
\hline Complications & No.of cases & Class 1 & Class 2 & Class 3 & \% \\
\hline $\begin{array}{c}\text { Abruptio } \\
\text { Placentae }\end{array}$ & 5 & 1 & 2 & 2 & $27.7 \%$ \\
\hline DIC & 4 & 2 & 2 & - & $22.2 \%$ \\
\hline $\begin{array}{c}\text { Acute renal } \\
\text { Failure }\end{array}$ & 5 & 1 & 2 & $27.7 \%$ \\
\hline $\begin{array}{c}\text { Pleural } \\
\text { effusion/ } \\
\text { ascites }\end{array}$ & 8 & 4 & 1 & - & $44.4 \%$ \\
\hline $\begin{array}{c}\text { Pulmonary } \\
\text { Edema }\end{array}$ & 1 & - & - & - & $5.5 \%$ \\
\hline $\begin{array}{c}\text { Retinal } \\
\text { Detachment }\end{array}$ & 1 & 1 & - & - & $5.5 \%$ \\
\hline $\begin{array}{c}\text { Intra cranial } \\
\text { Bleed }\end{array}$ & 1 & 1 & 1 & - & $5.5 \%$ \\
\hline Eclampsia & 2 & 1 & 3 & 1 & $11.1 \%$ \\
\hline Jaundice & 6 & 2 & & & $33.3 \%$ \\
\hline
\end{tabular}


In the present study of the 18 cases 15 cases $(83.3 \%)$ cases were preterm. The incidence of maternal complications in our study was higher compared to Hemanth et $\mathrm{al}^{3}$, with incidence of pleural effusion/ ascites being highest (44.4\%). The incidence of DIC was higher in Sibai et $\mathrm{al}^{8}$ study (38\%), compared to $22.2 \%$ in our study. The incidence of acute renal failure in our study was $27.7 \%$ which was higher compared to both Sibai et al and Hemanth et al. the incidence of abruptio placentae in our study was $27.7 \%$ which was comparable to Sibal et al. The incidence of pulmonary edema in our study was 5.5\% which was comparable to Sibai et al.The other complications reported in our study were retinal detachment, intra cranial bleed, eclampsia and jaundice.

The incidence of transfusion of blood and blood products in this study is as follows

\begin{tabular}{|l|l|}
\hline BLOOD OR BLOOD PRODUCT & NO. OF PATIENTS \\
\hline Fresh whole blood & 6 \\
\hline Packed cells & 2 \\
\hline Platelets & 4 \\
\hline Fresh frozen plasma & 4 \\
\hline
\end{tabular}

\begin{tabular}{|l|l|}
\hline MISSISIPI class & NO. OF PATIENTS \\
\hline Class 1 & 4 \\
\hline Class 2 & 4 \\
\hline Class 3 & 1 \\
\hline
\end{tabular}

Requirement of blood and blood products was high in class 1 and 2 compared to class 3 patients.

Pregnancy outcome in this study is as follows

Of 18 cases 11 delivered vaginally

\begin{tabular}{|l|l|}
\hline Spontaneous vaginal delivery & 5 \\
\hline Induced & 8 ( 6 delivered vaginally) \\
\hline
\end{tabular}

Lower segment Cesarean section was done in 7 cases

\begin{tabular}{|l|l|}
\hline Obstetric indications & 5 \\
\hline Induced cases & 2 \\
\hline
\end{tabular}

Of the 18 patients 5 had spontaneous vaginal deliveries. 8 cases were induced of which 6 delivered vaginally and 2 were delivered by cesarean section. 5 cases were delivered by cesarean section for obstetric indications.

Perinatal outcome in this study is as follows

\begin{tabular}{|c|c|c|c|c|c|}
\hline & No. of pts & Class 1 & Class 2 & Class 3 & $\%$ \\
\hline IUGR & 8 & 1 & 1 & 6 & $50 \%$ \\
\hline Prematurity & 2 & 1 & - & 1 & $11.1 \%$ \\
\hline IUD & 6 & 2 & 3 & 1 & $33.3 \%$ \\
\hline Live birth & 12 & 2 & 2 & 8 & $66.6 \%$ \\
\hline $\begin{array}{l}\text { Respiratory } \\
\text { distress }\end{array}$ & 4 & 1 & 2 & 1 & $22.2 \%$ \\
\hline $\begin{array}{l}\text { Low } 5 \mathrm{~min} \\
\operatorname{APGAR}(<7)\end{array}$ & 4 & 1 & 2 & 1 & $22.2 \%$ \\
\hline Neonatal death & 3 & 1 & 2 & - & $16.6 \%$ \\
\hline
\end{tabular}

The perinatal outcome in our study was as follows. $50 \%$ of the cases had Intra uterine growth retardation. The incidence of intra uterine deaths was 33.3\%(6 cases)which was high compared to Sibai et al and Hemnth et al. The incidence of neonatal deaths was $16.6 \%$ which was comparable to both studies. The incidence of Respiratory distress and low 5min APGAR score $(<7)$ was $22.2 \%$ each.

Perinatal mortality in this study is as follows

\begin{tabular}{|l|l|}
\hline INTRA UTERINE DEATHS & 6 \\
\hline Abruptio placentae & 5 \\
\hline Meconium aspiration & 1 \\
\hline
\end{tabular}

\begin{tabular}{|l|l|}
\hline NEONATAL DEATHS & 3 \\
\hline Neonatal sepsis & 2 \\
\hline Respiratory distress & 1 \\
\hline
\end{tabular}

The causes of intra uterine deaths were abruption in 5cases and meconium aspiration in 1 case. The causes of neonatal deaths were sepsis in 2 cases and respiratory distress in 1 case.

The reason for higher morbidity in our study is delay in identifying the problem by referring doctors. Most of the cases were referred to us at a late stage. Biochemical changes identified HELLP syndrome and termination of pregnancy was planned upon admission to the hospital. 
In all cases of severe pre eclampsia with renal failure and accumulation of fluid in $3^{\text {rd }}$ space ( pleural effusion/ascites), restriction of fluids to $<80 \mathrm{ml} / \mathrm{hr}$ or $1 \mathrm{ml} / \mathrm{kg} / \mathrm{hr}^{10}$ is recommended to reduce the incidence of pulmonary edema. Renal impairment was corrected within $48 \mathrm{hrs}$ of delivery.

Pregnancies complicated by HELLP syndrome are associated with poor outcome for the mother and fetus. Maternal complications are common and potentially life-threatening. Disseminated intravascular coagulation, placental abruption and acute renal failure are common ${ }^{5}$. Other complications include eclampsia, cerebral hemorrhage, adult respiratory distress syndrome (ARDS) and hypovolemic shock. Haematoma, infarction and rupture ${ }^{6}$ of the liver have also been described.

Perinatal mortality ranges from $10-20 \%$ in HELLP syndrome ${ }^{7}$. This high mortality is associated with preterm birth and its complications including growth retardation and abruption of placenta. Infants have high rates of respiratory distress syndrome, bronchopulmonary dysplasia, intracerebral hemorrhage, necrotizing enterocolitis and neonatal thrombocytopenia.

\section{Conclusion}

The presence of HELLP Syndrome accentuates the risk for adverse maternal - perinatal outcome. There is involvement of multiple organs. Presentation is variable, resulting in delayed diagnosis, and inappropriate medical and surgical treatments. Class I had maximum maternal morbidity and maximum incidence of transfusions.

This study uncovers only the tip of the iceberg as this is only a hospital based study. HELLP syndrome in non PIH cases were not evaluated. Many cases belonging to Class II and III can go unnoticed because of an uneventful course.

Outcome for mother and baby can be improved with better understanding of the disease process, consequent earlier diagnosis and improvements in maternal and neonatal intensive care standards. Restriction of fluids to $<80 \mathrm{ml} / \mathrm{hr}$ or $1 \mathrm{ml} / \mathrm{kg} / \mathrm{hr}^{10}$ is recommended to reduce the incidence of pulmonary edema in patients with renal failure ${ }^{10}$. Risk of recurrence is approximately $5 \%{ }^{3}$ Risk of pre eclampsia in subsequent pregnancy is $20 \%{ }^{3}$. Low dose aspirin prophylaxis may be of benefit ${ }^{9}$.

Anticipation of the problem and early identification of HELLP Syndrome will reduce the complications associated with this condition.

\section{References}

[1]. Abraham KA, Connolly G, Farrell J et al. The HELLP syndrome, a prospective study. Ren Fail 2001;23:705- 13.

[2]. Vigil-De Gracia P. Pregnancy complicated by preeclampsia- eclampsia with HELLP syndrome. Int J Gynaecol Obstet 2001;72:1723.

[3]. Hemanh et al, J Obstet Gynecol India Vol. 59, No. 1 : January/February 2009 pg 30-40

[4]. High Risk Pregnancy: Management Options, 4e JAMES, STEER, WEINER AND GONIK. Ch-35 HYPERTENSION by GUSTAF DEKKER,pg:608

[5]. Reubinoff BE, Schenker JG. HELLP syndrome-a syndrome of hemolysis, elevated liver enzymes, and low platelet countcomplicating preeclampsia-eclampsia. Int J Gynaecol Obstet 1991; 36:95-102.

[6]. Saura P, Blanch L, Capdevila E et al. Spontaneous rupture of the liver during pregnancy. Intensive Care Med 1995; $21: 95-96$.

[7]. Van Pampus MG, Wolf H, Westenberg SM et al. Maternal and perinatal outcome after expectant management of the HELLP syndrome compared with preeclampsia without HELLP syndrome. Eur J Obstet Gynecol Reprod Biol 1998;76:31-6.

[8]. Sibai BM, Ramadan MK, Usta I et al. Maternal morbidity and mortality in 442 pregnancies with hemolysis, elevated liver enzymes, and low platelets (HELLP syndrome). Am J Obstet Gynecol 1993;169:1000-6.

[9]. CLASP study: A randomised trial of low-dose aspirin for the treatment and prevention of preeclampsia among 9364 pregnant women. Lancet 1994;343:619-29

[10]. RCOG guideline No.10(A) March 2006 